\title{
Jade's Dying Body: The Ultimate Reality Show
}

\author{
by Tony Walter \\ University of Bath
}

\author{
Sociological Research Online 14(5)1 \\ <http://www.socresonline.org.uk/14/5/1.html> \\ doi:10.5153/sro.2061
}

Received: 11 Sep 2009 Accepted:11 Nov 2009 Published: 30 Nov 2009

\begin{abstract}
The article analyses the scale of, and reactions to, print media coverage of the dying from cancer in 2009 of young British media celebrity Jade Goody. Some sociologists have argued that death is sequestrated, with the dying body particularly hidden and problematic; hence the sociological significance of the intense and high profile coverage of Jade's final weeks. In particular, the baroque emotionality of press photos, especially those which glamorised her baldness (the result of failed chemotherapy), challenges the sequestration thesis. Reactions were complex, with criticism of her public dying mixed with criticism of reality television in general, together with class prejudice. New media's blurring of public and private creates new arenas for publicising the bodily, personal and emotional experience of dying, while at the same time affirming the public/private boundary so that the ordinary dying of ordinary people remains substantially hidden.
\end{abstract}

\section{Keywords: Baroque, Body, Cancer, Celebrity, Death, Dying, Media, Reality Television, Sequestration, Social Class}

\section{Introduction}

\begin{abstract}
'She is the first reality television star to die as she lived, riding high atop the nation's most pungent newspaper headlines, dominating television bulletins and news programmes. For many millions of people, whether they liked it or not, her bald head, deep dimples and increasingly distressed expression became as familiar as their own thumbs.' (Moir 2009: 8)
\end{abstract}

1.1 There is sociological debate as to the extent to which dying is sequestrated in late modern society converted from a human experience into a medical technicality, hidden from public view, marginalised from everyday constructions of reality as orderly and predictable, and turned into a private experience (Elias 1985; Giddens 1991; Mellor and Shilling 1993; Willmott 2000). This article analyses the very public dying from cancer in early 2009 of twenty seven year old British reality show contestant and celebrity Jade Goody; the story of her dying, visual images of her dying body, and the meanings she gave to her dying were all made very public. Does the unprecedented scale of media coverage of her dying, along with the by no means entirely negative reactions to it, challenge the sequestration thesis? To answer this, the article examines the scale and intensity of the coverage, and some reactions to it. More detailed analysis of the content of the media coverage is provided in another, hopefully forthcoming, article.

1.2 Jade died as she lived, in the full glare of the media, and specifically to raise funds for her two young boys' future education. Her dying is by far the most public in Britain in my lifetime. By comparison, the content of the frequent news bulletins about Pope John Paul II's final days was sparse and, while a number of journalists have written about their terminal cancer or AIDS, they have done this in relatively low circulation upmarket newspapers - readers could choose whether or not to read such columns. But in early 2009, readers of British redtops (downmarket tabloid newspapers) and certain celebrity magazines could not avoid Jade's dying, which for several weeks dominated both front and inside pages. If dying is largely hidden in contemporary society, Jade's dying was unavoidable.

1.3 She was dying at a time when the banking system was collapsing, threatening global recession. For several weeks shortly after her death, a more provincial scandal dominated the British headlines concerning the apparently extravagant expenses claimed by members of parliament, prompting widespread distrust of Britain's MPs. The first half of 2009 thus inverted certain understandings of reality and fantasy. Hitherto, the more upmarket news media portraved economics and politics as the real world, in contrast to 
the fabrication and shallowness of television game shows and reality shows and the fantasy world of celebrities. But now the world seemed upside down. It turned out that bankers and borrowers had been living in a fantasy world, as had British MPs. Meanwhile, an ill-educated, brash young working class woman was reminding all Britain of one basic reality: human mortality (Bunting 2009). This may not, of course, have entailed a reversal for the redtops whose daily offerings routinely prioritise love and death over economics and politics, but even the broadsheets eventually had to comment on the Jade phenomenon.

\section{The sequestration thesis}

2.1 The sequestration thesis (Mellor 1993; Mellor and Shilling 1993) is rooted both in earlier work in the sociology and history of death, and in Giddens' (1991) argument about the fragility of ontological security within modernity. Without delving into all aspects of the thesis, in this article l extract three elements: that in modernity i) death, and in particular the dying body, is hidden from general view, ii) the experience of death and dying is cut off from everyday routines, and iii) dying people are left to themselves to make sense of their experience. In other words, dying is hidden, and its meaning privatised.

2.2 First the hiding of death. Historian Philippe Ariès (1974; 1983), proposed that death in modern societies is forbidden, but more demonstrable is his more modest claim that death is hidden. The dying are removed not only from society into hospitals and nursing homes, but even within those settings into side wards and rooms away from other patients and residents (Hockey 1990; Komaromy 2000). Bereaved individuals no longer wear black armbands, mourning clothes or recognisable mourning jewellery, so are invisible (Barratt 2009). Inquests no longer take place in inns (Burney 2000), and (in the UK) crematoria are not visible from public highways, contrasting with some of the more spectacular Victorian cemeteries that were visible from afar as a memento mori (Curl 1993). There are exceptions, not least among religious and ethnic minorities, but the overall picture of hidden death is recognisable.

2.3 Second, the privatising of meaning. Blauner (1966) argued that most members of advanced industrial societies die in old age, having fulfilled their major responsibilities in work and childrearing, so do not leave so much of a social and economic gap. They may, however, be deeply mourned by spouse or children who have accumulated many decades in which to develop intimacy with the now deceased. Death and loss have therefore ceased to hold significance for society, their meaning becoming increasingly private. At the same time, Mellor and Shilling (1993) point out that late modern individuals cannot find meaning under the traditional sacred canopy that Berger (1969) argued had been provided by religion and other authorities; rather they must find meaning for themselves, in dying as in living. Death is therefore absent in public, but all too present in private.

\section{Sequestration and the mass media}

3.1 The sequestration thesis has been challenged on a number of grounds, not least the high visibility of death in the mass media. Death, disaster, murder, and mourning are staple diets of both upmarket and downmarket mass media. A high percentage of stories and pictures on the front pages of British newspapers concern death (Walter et al 1995), while death is pervasive in American television drama (Mcllwain 2005). The death of others is therefore not cut off from audiences' everyday routines of breakfasting, commuting and so on; indeed, the mediated deaths of strangers routinely accompany these daily activities. If, outside the media, conversational norms inhibit expressions of sorrow or grief (Elias 1985: 26-7), Mellor's thesis may need to be reversed: death is highly visible in public media, but avoided in private conversation.

3.2 The deaths the media portray, however, are rarely of a kind audiences are likely themselves to face. People in the national news die of murder, accident, suicide, disaster, and war. And they are often 'other': either already famous (Pope, President, movie star), or belonging to less than fully modern societies (victims of starvation or civil war). The media typically deal in death at a distance, not the deaths audiences in advanced industrial societies are themselves likely to face.

3.3 There are exceptions. Newspaper and magazine articles about common life threatening conditions are legion. Clive Seale (2002a, b) found over two thousand articles in the English-language press in just one week containing the words 'cancer' or 'leukemia'. Art photographic exhibitions of the dying body may be accessed in person or through the internet. ${ }^{[1]}$ And there are many published first person accounts of illness, dying and loss, what Hawkins (1990) terms pathographies, in the form of books newspaper columns, television documentaries, and blogs (autobiographical cancer books include Picardie 1998, Diamond 1999, Tomlinson and Tomlinson 2005). Bingley et al (2006) show that pathographies by those facing death, as a genre, date from the 1970s, and that the vast majority are written by people with cancer; Bingley et al explain this focus on cancer not in terms of audience demand but in terms of the specific experience and practicalities of this disease compared to, say, heart disease, stroke or dementia. Whatever the reasons, it is cancer that dying people write about, and audiences seem not to tire of their pathographies; Jade therefore wrote for an established market in which a deadly disease, cancer, is widely portrayed.

3.4 Cancer holds a special place in the popular imagination, with cancer patients typically portrayed by journalists as heroically battling against an insidious enemy (Seale 2002a,b). Dixon-Woods et al (2003) have questioned the relationship between media representations of cancer and how families themselves describe the experience of cancer. Autobiographical pathographies present themselves as telling it like it is', but there are questions of self-censorship over the more painful aspects of dying (Armstrong-Coster 2005); pathographies tend to focus on the devastating news of diagnosis and the roller-coaster hope for curative treatment more than the final weeks of dying (Bingley et al 2006); and crucially, nobody is forced to read or watch these pathographies. What makes the Goody pathographies unusual is her being given the cancer diagnosis while appearing on a reality TV show, and the relentless publicising of the details of 
3.5 Since the early 1990s, there has been a renaissance of new mourning rituals in all modern western countries, prompting researchers to coin new terms such as 'spontaneous shrine' (Santino 2006), 'rituals in abundance' (Lukken 2005), and 'the new public mourning' (Walter 2008). News media highlight the mass mourning after famous deaths. Also, funerals are becoming more personal, celebrating and enhancing memories of the deceased (Garces-Foley and Holcomb 2006). All this links with pre-occupations with memory and (Giddens 1991) the reflexive self, both inside and outside the academy. But if late modern people and their media are comfortable with memory, they seem less comfortable with the materiality of dying and dead bodies. Lawton (1998) observed that even hospices, devoted to breaking taboos about death, find problematic the smelly, suppurating and fungating tumours that are the unwelcome lot of some patients. Physical rot and decay offend civilised sensibilities (Elias 1978), possibly all sensibilities (Miller 1997).

3.6 If the materiality of the dying body continues to be problematic, even as popular culture and mass media celebrate memory and mourning, then what is notable about Jade's dying is not the coverage of the public mourning after her death, which was similar to that after other public deaths. What was truly remarkable were the day-by-day front page pictures of her dying body, the headlines of her physical and mental anguish, the stories of her being dashed to hospital for emergency pain-relieving operations or of her begging to be let home to die. Here were stories and pictures, hard to avoid, of how a young working class woman experienced dying of cancer. This was new, and for sequestration theorists as for many commentators, unexpected. The private had become public.

3.7 In order to examine key elements of the sequestration thesis - the hiding of the dying body, the removal of dying from everyday routines, and the privatising of meaning - I examine 1) the scale, directness and unavoidability of print media coverage, focussing on the most visible coverage, namely the redtops and OK! magazine in the last month of Jade's life; and 2) some public reactions, expressed in broadsheet blogs and e-letters columns. If the sequestration thesis is correct, such intense media coverage of a young woman dying of cancer would have deprived audiences of their 'ontological security', and in turn they would be expected to react negatively. Did they? Finally, the article asks whether reality television and celebrity culture have radically reconfigured the relation of private and public, and what implications there might be for the sequestration of dying. Might the dying of a celebrity provide a frisson of excitement that guarantees high audience ratings but does not actually challenge everyday dying?

\section{Scale and directness of media coverage}

4.1 After an inauspicious childhood with a criminal father and drug addicted mother, in 2002 while in her early twenties Jade Goody entered the British television reality show Big Brother 3 . While most contestants become at best ephemeral, dispensable celebrities (Collins 2008), what Rojek (2001) terms celetoids, Jade - though not winning the show - was more successful than any other British reality show contestant in turning her new-found fame into a media career, launching her own profitable perfume line and writing a best selling autobiography (Goody 2009a). Her direct, tell-it-like-it-is manner, though well suited to reality TV (Kompare 2009), was not to everyone's taste, indeed she was widely vilified as ignorant, loudmouthed and racist.

4.2 In August 2008 while live on the Indian reality show, Bigg Boss, she was telephoned by her doctor in London who informed her that test results showed she had cancer that was sufficiently serious to warrant her immediate return home. (Her receiving the news is still viewable on YouTube) After a number of treatments, it was confirmed on 4 February 2009 that the cancer was terminal; she married Jack Tweed on 22 February, she and her two young sons were christened on 7 March, and she died on 22 March. Many twists kept the story going: Jack had been convicted for assault and was on electronically tagged curfew so most nights could not stay with Jade; one night an intruder entered Jade's hospital room; and so on. Jade's dying, like her living, was never dull, so there was no shortage of sub-stories to keep the overall story of her dying on the front pages.

4.3 Jade invited the media and their audiences to witness her dying, for at least three reasons. [2] First, she loved the limelight, made money from it, and saw no reason to change this just because she was dying. Being herself, in public, was her trade. Second, she signed lucrative media deals for the story of her remaining weeks, in order to provide funds for her two young sons' education so they could have a better start in life than she had; the deals were primarily with OK! magazine and Living TV. Third, she wanted to encourage women to have cervical cancer smear tests. To these ends, she hired controversial publicist Max Clifford to manage the media coverage of her dying, and she published her own pathography, a diary covering the seven months from first diagnosis to a week before her death (Goody 2009b).

4.4 Jade's dying was unprecedentedly public. Whereas audiences had to choose whether or not to read or watch previous pathographies, redtop readers in early 2009 had no such choice. Jade's dying was on redtop front pages most days for several weeks. Not only was it on the front page, often it was the only item on the front page, comprising headline and colour photo and a few lines of text. If you bought the paper, or even if you just glimpsed it on the newsagent's shelf, you could not but see the headline and picture. Jade was moved off the redtops' front pages only occasionally by other tragic deaths such as those of actress Natasha Richardson and the six year old son of British politician David Cameron, and by the ongoing trial of Austrian child abuser Josef Fritzl.

4.5 Jade's front page coverage was particularly prominent in The Sun, the UK newspaper with the largest circulation, and the Daily Star, with the fifth largest, though sparse in non-redtop tabloids such as the Daily Mail (second largest circulation). Coverage was also prominent in the UK's best selling Sunday paper, The News of the World. [3] OK! magazine had recently slipped to number two in the circulation figures for UK celebrity magazines, ${ }^{[4]}$ and doubtless hoped its exclusive deal with Jade for pictures of her wedding would 
help restore it to number one. Coverage of Jade's dying was particularly extensive also because it continued daily to the day of her death, with her active participation up to a week before; by contrast, most pathographies cease several weeks or months before the end. Jade chose to go public not only about her cancer and its treatment, but also about the final weeks of her dying.

4.6 Unlike many previous cancer pathographers (Seale 2002b;Bingley et al 2006), Jade was far from cerebral. She called a spade a spade; some vilified her rudeness and ignorance, others loved her lack of guile and honesty about the realities of class in modern Britain. Indeed, she played on her lack of education, increasingly coming to be seen as an ordinary, if originally less than fortunate, working class girl who made good - a kind of Princess Diana from the wrong side of the tracks. Her 2007 verbal attack on Bollywood star Shilpa Shetty, widely reported as racist, may have had more to do with social class and her desire to expose and strip away what she saw as hypocrisy and pseudo refinement, a desire she then in 2009 applied to dying.

\section{Reality TV and dying.}

4.7 Jade was a product of Big Brother (Bignell 2005; Hill 2005). Such shows thrive on participants who, like Jade, are direct and confrontational. Though previously vilified as loud mouthed and inconsiderate, by 2009 many readers and journalists recognised that - whatever else she was - she was candid, honest, and open. This differentiated her from most celebrities, especially those who achieve celebrity through talent, who strive to maintain a private self behind the public persona. The fascination of many celebrities for tabloids and celebrity magazines is precisely the question of who they are beneath the image - has George Best really given up alcohol? is the Beckhams' marriage in trouble? who was the real Michael Jackson? No such questions were asked about Jade; there was no mystery about her; little remained private. The ghost writer of one of her autobiographies commented The Jade I got to know was more open, honest and candid than any celebrity l'd every met.... Jade wore her heart firmly on her sleeve in a way noone else, especially those in the public eye, would dare.' (Cave 2009; vii) True to this identity, she hid from public view neither her cancer nor its consequences for herself and her family.

4.8 Unlike some earlier reality shows that celebrated labour, for example that of airport or hospital workers, Big Brother cut participants off from the world of work, cocooning them in a world of leisure and consumption, revealing intimate relationships normally deemed private (Couldry 2003; Sparks 2007). This underlies some of the criticism directed at the programme. Jade's time on Big Brother 3 included time under the bedsheets with a fellow participant, though the press could only speculate as to the details. [5] Whether or not Jade was the first to have intercourse on UK Big Brother, she was certainly the first reality television contestant to display the similarly hidden process of dying - even if primarily through print media. Apprenticed through and subsequently making a living out of reality shows, Jade had created an identity out of making her private world public; she therefore was not averse to going public about the normally private business of dying. Jade's 'complete inability to construct a public persona that was anything other than her clumsy, often crude, vulnerable but bafflingly uncrushable self' (Brooks 2009) made her the ideal reality show contestant, and she became the first British celebrity whose fame derived purely from a reality show.

4.9 In the history of reality television (Murray and Ouellette 2009), Jade's dying signifies a new development. Early fly on the wall documentaries, such as Candid Camera (from 1948) and then full length treatments of private life such as An American Family (USA, 1973) and The Family (UK, 1974), purported to film reality as it was already happening within streets and homes. Later came the so-called reality show, in which participants were filmed in an artificial situation such as the Big Brother house, a situation viewers know is a staged unreality and which they enjoy as such. It was from this unreal real world that Jade emanated, yet her dying was really real; reality television thrives on unanticipated, unscripted moments of high emotion (Couldry 2003: 127) and the moment in which her cancer was diagnosed on Bigg Boss provided a dramatic example. It was precisely Jade's apprencticeship in reality TV that then enabled her to present her dying to mass audiences. As one blogger commented the day she died: [6]

'Her decision to hold on to the conventions of reality television while she was dying made us all feel uncomfortable. The joke about reality TV was it made everything so unreal; yet this cancer was real, and spreading fast. Viewers had difficulty getting their heads round that.'

\section{Pictures}

5.1 If Jade's words are very direct, so too are the colour photographs that are central to the print media coverage; they are direct both physically and emotionally.

5.2 In art historical style terms, the photographs are baroque. In many classical paintings, such as David's The Death of Socrates (1787), other figures surround the main figure, providing a frame though which the viewer looks at the main figure. By contrast, in baroque painting the colourful, often fleshy, main figure or figures fill the scene, sometimes looking straight at the viewer, sometimes seemingly tumbling out of the front of the picture and mocking any idea of frame (Gombrich 1978). Though the baroque never found as much favour in British art and architecture as in some other European countries and certainly does not characterise contemporary British funerary sculpture (Frazer and Oestreicher 1998), it does typify British tabloid newspaper photography, with the subject - in this case, Jade - rarely framed, apparently leaping off the page at the viewer. In pictures, Jade is, as it were, in your face - reflecting her original Big Brother representation as brash, loud, in your face. This tabloid picture genre confirms her media personality; the pictorial Jade cannot be ignored, not even by browsers in the newsagents who have no intention of buying a redtop. 
baldness. At her two last public (and extensively photographed) performances, her wedding to Jack Tweed and the christening in a hospital chapel of herself and her two children, she chose not cover her bald head. Bald photographs adorn both the cover and inside pages of the glossy wedding and christening issues of OK! (March $10^{\text {th }}, 17^{\text {th }}$ ) and of the tabloids. At a pre-wedding photoshoot, she got her bridesmaids to cover their heads with swimming caps, imitating her baldness (News of the World, Feburary $22^{\text {nd }}$, p.5)

5.4 The pictures of dying Jade are ambiguous. On the one hand, much of the time she does not look very ill. On the other hand, she chose to reveal her chemotherapied bald head. Hair loss - sign of the ravages of cancer treatment (known by the time of her wedding to be unsuccessful) - is usually hidden by cancer patients under wigs, hats and headscarves. Some pictures of Jade, especially before her terminal diagnosis, reveal a covered head, but she then abandoned this for her most public performances. At wedding and christening, the bald headed, wedding-gowned or hospital-gowned Jade is depicted holding her two young children or kissing husband Jack; a sign of death counterposed by signs of youth, vitality and love.

5.5 Glamorous pictures of bald Jade in her traditional white wedding dress adorn not only the front covers of magazines and newspapers, but on her death become for many media her defining image. Davies (2007) has observed that, when a famous person dies, the picture splashed all over the media rarely depicts their deathbed or old age, but shows them at the height of their powers. Not so Jade. Tribute issues (e.g. OK!, $24^{\text {th }}$ and $31^{\text {st }}$ March; News of the World, $8^{\text {th }}$ March), and some of the dailies reporting her death (Guardian, Sun, $23^{\text {rd }}$ March), have on their covers as their defining image a classy picture of a smiling, bald, dying Jade. The covers of her autobiographies (Goody 2009a, 2009b) also feature her bald - kissing Jack, or in her wedding dress. It is as though dying is the culmination of Jade's career, her last act her finest, what she is to be remembered for.

Not everyone approved of this.

\section{Reactions}

6.1 If dying in modern society is normally hidden within private places, and if Jade's dying was unprecedently public, how did the public respond? The sequestration thesis would predict outrage. All these words, all these unavoidable pictures, of cancer destroying a young mother, they should undermine audiences' ontological security, their sense of an ordered, safe world in which to raise children; Giddens' late modern audiences would surely prefer Jade's decline to be reported like the Pope's, in occasional cautiously worded bulletins?

6.2 Outrage was clearly not the response of the redtops or OK! magazine, nor of the many who continued to buy these publications, nor of the two thousand readers who left condolence messages on the Sun's Jade tribute website. Max Clifford, admittedly not an unbiased source, stated on the 18th February that 90 per cent of thousands of letters coming in from all over the country were 'incredibly supportive of her'. [7]

6.3 But there was disquiet in some quarters. Irish Mail columnist Fiona Looney wrote that Jade should have 'a shred of dignity'and spend her final days with the kids, not the cameras. Colette Fitzpatrick, Irish TV3 News anchor and Midday presenter, discussed Fiona Looney's column on air and received 'Tons of emails/calls about it - some from oncology nurses and patients who disagreed with the publicity surrounding Jade Goody. Tons also, from the general public some of who agreed with her. ' ${ }^{8]}$

6.4 When someone dies, criticism is usually muted till they are decently buried, but in its issue announcing Jade's death, the middle-brow Daily Mail included a two-page-spread (Moir 2009) critical of the 'morbid hullabaloo' surrounding her dying. Moir asked 'Should we even have been privy to these distressing and most personal of images?' In its issue reporting her death, The Daily Telegraph quotes negative reaction from two 'expert' sources (23rd March, p.9): John Beher of MediaWatch asked if 'the public really needs to see the details of someone's death played out', while Thelma Said, a nurse who looks after terminally ill patients, agreed: 'We do not need to know which organs are failing every day and do not need to see pictures of her degenerating. It is sad that we... have an appetite for this type of show.'

6.5 The Daily Mail and Daily Telegraph are among Britain's more culturally conservative and middle class newspapers, but contributions to a Telegraph blog ${ }^{[9]}$ contained a significant proportion sympathetic to Jade, such as: 'She caught a big, albeit artificial, wave, then rode it to the end. Good for her. And she exited this world with a nicely turned flourish. Her detractors stink of envy. God bless the young lady.'

6.6 The Guardian prides itself on its intellectualism and liberalism, but scrutiny of 257 contributions posted to the Guardian the day after she died ${ }^{[10]}$ reveals more hostility than in the Telegraph's postings. Some found the public exposure of her dying distasteful:

'Well we knew it was coming, I do hate the public dissection of someone's dying months however, Pope John Paul II was bad enough... Please let this not be repeated.'

'she had an absolute right to live \& die as she chose but i for one am glad this undignified circus is at an end.'

6.7 Others resented their inability to avoid the coverage, even in 'quality' papers such as the Guardian:

'I have always regarded the Jane Goody story as a prime example of an intrusive news story: a story which has no intrinsic value but which the media chooses to force on me and the thousands of others who frankly have no interest.' 
I've had to involuntarily endure months of maukish sentimentality to the point of pornography for a dying stranger... the commercialisation of her death was obscene and indefensible.'

6.8 For many, what disturbed them was not particularly Jade's dying, but the whole Jade media bandwaggon over the previous seven years. (Maybe Guardian readers are more likely than Telegraph readers to have taken sociology or media studies courses, and hence cynical of the media?) Some, though, were disturbed by the critical comments:

'Fucking hell guys, what a bunch of heartless bastards.'

I too was sickened by several of these broadsheet readers' e-comments. But clearly they were sickened by Jade and her media. Several re-asserted the importance of political and economic events worldwide over the death of a non-entity celebrity. Some living overseas despaired that even the BBC gave air time to celebrity non-events such as Jade's dying, one commenting:

'I now rely mainly on Al-Jazeera English, which is still capable of understanding the distinction between news and gossip. Not a single mention of Goody.

6.9 Others, though, approved of her public dying:

'I liked Jade. Honest, raw, well intentioned and flawed.'

'I think what she did was great, she showed that pain, going bald and dying should be out in the open, too many women feel embarassed by the loss of hair during chemo and many other things that happen to your body. Jade allowed all of that to be okay for so many women who are struggling with this disease.'

6.10 Among the Guardian readers who posted their views, opinion was split - about Jade's moral qualities, about whether she should have gone public with her dying, about the extent to which she was manipulated by the media, and about what the cult of celebrity says about modern Britain.

\section{Culture wars}

6.11 This is not the first time that media coverage of death and dying has prompted negative reaction. Many Britons had complained twelve years earlier about the difficulty of avoiding the wall-to-wall coverage of the mourning for Princess Diana (e.g. Jack 1999). There were complaints too about the advertising campaign for the second series of television's Six Feet Under featuring a family who run a funeral home street posters were criticised for being unavoidable, bringing death into public view (Harper 2009), a clear case of matter out of place (Douglas 1966). Hostile reaction in a number of countries to the proliferating spontaneous street shrines and other personal memorials that escape the bounds of the cemetery have been analysed by Petersson (2010) in terms of the breaking through of the abject into everyday life (Kristeva 1982).

6.12 Whether such reactions and associated social theories point to a specific need for death to be kept in its place and remain private; or for fateful moments of any kind to be kept under wraps; or for anything that once was private to remain private, is debateable. I have noted that reality shows can offend because they put under the camera lens all kinds of previously private behaviour (Sparks 2007). Many contributors to the Guardian blog are disturbed by the entire phenomenon of reality shows and the Jade Goodys they create.

6.13 Cultural battles over the 'proper' way to deal with death may in part concern taste. Prothero (2001) has argued that the belated (1990s) popularity of cremation in the USA derives in part from baby boomers' emerging tastes. A generation that liked to display itself as green and responsible, rejecting gas guzzlers for more modest automobiles, is now rejecting the baroque mid-twentieth century all-American funeral's fancy casket and Cadillac hearse, and opting for a simpler funeral that symbolically reflects postmaterialist values. Jessica Mitford's (1963) best selling critique of American funerals resonated with baby boomers not because they agreed they were too expensive, but because they thought them tawdry. Likewise, a recent British blogger has suggested that taste lies at the heart of rules against plastic windmills and teddy bears on graves and at memorial benches. ${ }^{[11]}$ It is possible that for some the redtops' offensiveness, and Jade's in particular, is their poor taste - their baroque emotionality and directness. The painful emotions of dying should be kept decently private, or at least more carefully composed and framed.

\section{Class wars}

6.14 Many negative responses concerned social class. Some broadsheet journalists and readers sneered at Jade's lack of education and lack of talent, and were appalled that someone with so little ability should do so well in modern Britain. Middle class beneficiaries of a meritocratic society objected to Jade providing an unmeritocratic role model to young girls; they need not study or develop their talents but simply gain entry to a reality television show and they will be made. The lead article in the Guardian's issue reporting her death argued:

'Many of the broadsheets deplored her vulgarity and the high profile she was gaining despite her palpable lack of talent... Pulsing underneath it all, however, was the distinct throb of fear. Because despite the supposed democratisation of television, the truly uneducated, those marked by true poverty and deprivation, rarely appear in our light entertainment schedules. And suddenly, there was Jade, an unapologetic and unadorned symbol of all sorts of uncomfortable truths...' (Mangan 2009: 1) 
6.15 Jade's offence was not just that she was telling Britain, whether it liked it or not, what it is like to die of cancer, but that this new death educator had herself no education, taste or style. Times columnist Matthew Parris [12] suggests that There's an awful lot of snobbishness in some of the middle class disapproval of this.' He notes that when fellow Times columnist John Diamond, who like Jade Goody continued to write publicly about his life, even though dying of cancer, 'You didn't get this kind of middle class sneering you're now getting with Jade Goody.' Of course, Diamond's weekly inside page column was not in people's faces in the way Jade's almost daily front page photos were, but the class snobbery is evident in many middle class comments. Other broadsheet columnists made the comparison with Diamond; Johann Hari (2009) observed that nobody said Diamond was 'exploiting' his cancer by writing about it, whereas Jade's courting of the media so she could finance her children's future private education was evidence, for some, of her 'vulgarity'. Parris continued 'All classes like this kind of human interest story, but the middle classes like to overlay that with a certain class ridden dislike of working class people. Some of the broadsheet papers are now getting the best of both worlds - both the dislike, the derision, and the fascination.' Though they shied away from day to day coverage of her dying, all four broadsheets and the BBC extensively reported Jade's death.

6.16 Upmarket columnist Toby Young (2009) disputes that middle class reactions to Jade were snobbish. 'I was constantly struck by how little snobbery I encountered in people's attitudes to Jade's illness. On the contrary, nearly everyone I met was genuinely sympathetic.' His experience is reflected in the sympathetic comments from Daily Telegraph readers to which I have already alluded. Young links middle England's sympathy for Jade with the possibility for the first time in forty five years that an old Etonian (MP David Cameron) might become prime minister; in post-Blair Britain, 'even Jade Goody could embrace private education without jeopardising her status as a working-class hero.' Economic inequality has increased in recent decades, but Young argues that reactions to Cameron and Goody are evidence that British prejudices against both lower and upper classes have dissipated.

\section{A personal reaction}

6.17 I started to take an interest in Jade's dying in late Februrary 2009, just after I had myself spent the previous two months helping care for a friend dying of prostate cancer. It may be significant it was not till Phil died that I took any research interest in Jade. Reading about her final weeks may have had an unintended benefit helping me digest my recent experiences with Phil; at any rate, I could read the coverage with equanimity. That suddenly changed in June when the mother of a good friend died, this time not of cancer. As I tried to support my friend as she prepared for what we feared might be a difficult funeral, I resented being sucked into a media story that was so much more unreal than the grief I was currently having to deal with. During those days, I wanted to live in my friend's world, not Jade's. Only after attending the funeral, could I return to my researches in Jadeology.

6.18 My own reactions indicate that reactions to Jade within any one individual need not be fixed. They may depend on the individual's own experience, or lack of experience, of dying and mourning. For those distant from dying, Jade's breaking the normal bounds of privacy may have been informative, illuminating a normally hidden reality. For those immersed in dying or mourning, it may have felt inauthentic to be drawn into the dying story of someone they did not know; for others, and I have anecdotal evidence of this, identification with Jade's private-made-public sorrows may have added to their own.

\section{Conclusion}

7.1 In this article, I have tested the sequestration thesis by looking at the scale of the media coverage of Jade's dying, and reactions to it. First, the scale and directness of coverage challenge the thesis that dying is necessarily sequestrated in contemporary Britain. Previous eruptions of death into the public sphere have entailed mourning more than dying. Media coverage of dying tends to cover the deaths of the other. Dying of cancer is the staple fare of pathography books and blogs, but rarely dominates front page news for months. Jade was different: here was a young woman whose fame depended on her frankness and working class ordinariness, dying of a disease that is all too ordinary, and putting it on the front pages day after day. Here was a public intimacy (Berlant 2008) that nobody could avoid. The three key elements of the sequestration thesis on which I chose to focus were contradicted: Jade's dying body was not hidden from general view, her experience of dying was woven into the everyday routine of millions who read the redtops, and Jade chose to make public the meaning she gave to her dying.

7.2 Second, if the sequestration thesis is correct, reactions to the media coverage should have been uniformly hostile. But clearly, had reactions been uniformly hostile, the redtops would quickly have scaled down their coverage. In fact, reactions were mixed, suggesting either that audiences were divided over dying being reintroduced into public discourse, or that other factors were involved, notably issues of social class and social mobility. If for some, the public dying of this lower class woman was indecent, was it because it was public or because she was from a class some deemed not to deserve celebrity status and publicity?

7.3 Jade's will not be the last public dying. Late modernity has brought intimate relations into public focus (Giddens 1991). Audiences have grown used to witnessing the intimacies of family life, celebrities' love lives and the personal feelings of talk show participants; to this list may now be added dying. The most dramatic blurring of public and private was Jade being told on the second day of Bigg Boss, 'in a twist you wouldn't dare script', that she had cancer: 'That the moment anyone is told such news can be televised without their permission is a marker of how much times have changed since the internet, reality television and various other technologies started blurring the boundaries between public and private domains.' (Mangan 2009: 6) In Jade's dying, reality television, celebrity culture and news headlines blurred, so that Jade's ordinary dying displaced the extraordinary deaths through murder and disaster that form the staple news diet. Reality and artifice, private and public, became hard to untangle. Clearly, the technologically and 
financially driven domination of television by the reality show (Murray \& Ouellete 2009) has potential to bring dying out of the closet.

7.4 When the public / private split developed in the nineteenth century, it was strongly gendered, with women associated with home, men with work; women had feelings, men had reason. Women's domestic and interior worlds were very real, but not in public view, except perhaps in fiction. With the women's movement of the latter half of the twentieth century and the entry of many more women into the workplace, it became possible for women to go public about their private experiences, not least about grief (Simonds and Rothman 1992). Something over half of cancer pathographies are by women (Bingley et al 2006: 185). After the women's movement, the financial-technological development of reality television and associated media comprises a second major force able to transfer the experiences of ordinary women onto highly public stages and to dissolve the nineteenth century public-private divide.

7.5 If these new media offer new possibilities for publicising dying, does dying offer new possibilities for these media? Their prime aims are entertainment and diversion (Corner 2002). Jade's seven year career was based on entertaining and diverting her audiences. But coverage of her cancer and her dying - from initial diagnosis on Bigg Boss, though her televised bald-headed wedding, to her final weeks - confronted audiences with the very thing, mortality, from which, according to Becker (1973), humans most need diversion. Allusion to prolonged, painful dying in news media, obituaries or traditional documentaries has a considerable history; to present it in serial form over several weeks in the format of diversionary entertainment (reality television, celebrity mags, redtop gossip pages) is new.

7.6 This does not mean that everyday dying will change. Though media rituals (whether in the form of news, reality TV or celebrity magazines) legitimate the media's construction of its privileged access to reality (Couldry 2003), audiences knew that Jade's selling her experience of dying to the media is not an ordinary way to die. Jade's publicist Max Clifford, while profiting from Jade's public dying, made clear he would not have wished publicity for his own wife when she was dying from cancer. Celebrity culture and associated media need not challenge conventional everyday distinctions of public and private. Indeed, viewing this kind of exhibitionism enthrals audiences precisely because it invades, within the ritual context of the media, a private realm which, outside of the media, remains private. 'The thrill and ignominy of reality TV is based on the notion that while privacy is still the norm, it can pleasurably be violated by voyeurism and exhibitionism, as people clamor to see and show it all.' (Kompare 2009: 109) Through ritual transgression, the media affirm the public/private boundary (Couldry 2003).

7.7 Meanwhile, those not in the media spotlight continue to die of cancer. It seems unlikely that the media publicity surrounding Jade's dying will change the sequestration of those experiencing ordinary dying. They remain marginal to social and community life, residing at home, in nursing homes or hospital side wards. Their desequestration does not come about by the blurring - within media ritual - of private experience and public display that characterised Jade's dying. Jade's unsequestered dying does not, by itself, change everyday dying.

\section{Notes}

1 See for example the 2008 London exhibition by German photographer Walter Schels http://www.guardian.co.uk/society/gallery/2008/mar/31/lifebeforedeath?picture=333325401 and Hannah Wilke's 1994 New York exhibition http://www. feldmangallery.com/pages/exhsolo/exhwil94.html

2'Snobbish disapproval of Jade Goody' Radio 4 interview w Max Clifford \& Matthew Parris 18 Feb 2009 http://news.bbc.co.uk/today/hi/today/newsid_7896000/7896321.stm

${ }^{3}$ For circulation figures, see http://en.wikipedia.org/wiki/Newspaper_circulation\#United_Kingdom

${ }_{12}$ February 2009, "Closer overtakes OK! Magazine to become leading celebrity weekly" http://www.mediaweek.co.uk/news/880756/Closer-overtakes-OK-Magazine-become-leading-celebrityweekly/

5'Jade and PJ in Bedroom Antics', Mail Online http://www.dailymail.co.uk/tvshowbiz/article-122801/Jade-

PJ-bedroom-antics.html Retrieved 8.8.2009

6'Jade Goody: Death As Entertainment', http:///blogs.telegraph.co.uk/damian_thompson/blog/2009/03/22/jade_goody_death_as_entertainment 22 March 2009

7 See note 2, 'Snobbish disapproval'.

8 Email to Suzanne Power, forwarded to the author $2^{\text {nd }}$ April.

${ }^{9}$ See note 5, 'Jade Goody: Death as Entertainment'

10 http://www.guardian.co.uk/commentisfree/2009/mar/06/jade-goody-dies Accessed $23^{\text {rd }}$ March 2009, $7 \mathrm{pm}$.

11 http://www.goodfuneralguide.co.uk/2009/02/gnome-sweet-gnome.html 
12 See note 1: 'Snobbish disapproval'

\section{References}

ARIÈS, P. (1974) Western Attitudes toward Death. London: Marion Boyars Publishers.

ARIÈS, P. (1983) The Hour of Our Death. London: Penguin.

ARMSTRONG-COSTER, A. (2005) 'In Morte Media Jubilate (2): A Study of Cancer-Related Pathographies', Mortality 10(2): 97-102. [doi:10.1080/13576270500102880]

BARRATT, C. (2009) The Cultural Meanings of Contemporary Mourning and Memento mori Jewellery, London: University of the Arts, unpublished PhD thesis.

BECKER, E. (1973) The Denial of Death. New York: Free Press.

BERGER, P. (1969) The Social Reality of Religion. London: Faber.

BERLANT, L. (2008) The Female Complaint. Durham, NC: Duke University Press.

BIGNELL, J. (2005) Big Brother: Reality TV in the 21st Century. Basingstoke: Palgrave Macmillan.

BINGLEY, A. et al (2006) 'Making Sense of Dying: A Review of Narratives Written since 1950 by People Facing Death from Cancer and Other Diseases', Palliative Medicine 20(3): 183-195.

[doi:10.1191/0269216306pm1136oa]

BLAUNER, R. (1966) 'Death \& Social Structure', Psychiatry 29: 378-94.

BROOKS, L. (2009) 'The Curious Legacy of Jade Goody', Guardian 22 ${ }^{\text {nd }}$ March.

BUNTING, M. (2009) 'In Bewildering Times, Jade's Story of Sacrifice Offers us the Ultimate Reality', Guardian, $9^{\text {th }}$ March.

BURNEY, I. (2000) Bodies of Evidence: Medicine and the Politics of the English Inquest 1830-1926. Baltimore, Johns Hopkins University Press.

CAVE, L. (2009) 'Jade's Final Chapter', pp. vii-xxvi in Goody (2009b).

COLLINS, S. (2008) 'Making the Most out of 15 Minutes: Reality TV's Dispensable Celebrity', Television \& New Media 9(2): 87-110. [doi:10.1177/1527476407313814]

CORNER, J. (2002) 'Performing the Real: Documentary Diversions', Television \& New Media 3(3): 255-70. [doi:10.1177/152747640200300302]

COULDRY, N. (2003) Media Rituals. London: Routledge.

CURL, J.S. (1993) A Celebration of Death. London: Batsford.

DAVIES, C. (2007) 'Analysing Media Representation: Stardom and Spectres of Death', paper given at the $8^{\text {th }}$ International Conference on the Social Context of Death, Dying and Disposal, Bath.

DIAMOND, J. (1999) C: Because Cowards Get Cancer Too. London: Vermillion.

DIXON-WOODS M, Seale C, Young B, Findlay M, Heney D. (2003) 'Representing Childhood Cancer:

Accounts from Newspapers and Parents', Sociology of Health and IIIness 25(2): 143-164 [doi:10.1111/14679566.00329]

DOUGLAS, M. (1966) Purity and Danger. London: Routledge \& Kegan Paul. [doi:10.4324/9780203361832]

ELIAS, N. (1978) The Civilizing Process. Vol 1. New York: Urizen Books.

ELIAS, N. (1985) The Loneliness of the Dying. Oxford: Blackwell.

FRAZER, H. \& Oestreicher, C. (1998) The Art of Remembering, Manchester: Carcanet.

GARCES-FOLEY, K. and Holcomb, J.S. (2006) 'Contemporary American Funerals: Personalizing Tradition' p.207-227 in K. Garces-Foley, ed. Death and Religion in a Changing World. Armonk, NY: M.E. Sharpe.

GIDDENS, A. (1991) Modernity and Self-Identity. Oxford: Polity.

GOMBRICH, E.H. (1978) The Story of Art. Oxford: Phaidon, $13^{\text {th }}$ edn.

GOODY, J. (2009a). Jade: Fighting to the End. London: John Blake.

GOODY, J. (2009b). Jade: Forever in my Heart. London: HarperCollins. 
HARI, J. (2009) 'Jade Goody Showed the Brutal Reality of Britain, Independent on Sunday 22 March.

HARPER, S. (2009) 'Advertising Six Feet Under', Mortality 14(3): 203-25.

[doi:10.1080/13576270903016679]

HAWKINS, A.H. (1990) 'Constructing Death: Three Pathographies About Dying', Omega 22(4): 301-17.

HILL, A. (2005) Reality TV: Audiences and Popular Factual Television. London: Routledge.

[doi:10.4324/9780203337158]

HOCKEY, J. (1990) Experiences of Death, Edinburgh: Edinburgh University Press.

JACK, I. (1999) 'Those Who Felt Differently', Granta 60: 9-35.

KOMAROMY, C. (2000) 'The Sight and Sound of Death: The Management of Dead Bodies in Residential and Nursing Homes for Older People', Mortality 5(3): 299-315. [doi:10.1080/713686009]

KOMPARE, D. (2009). 'Extraordinarily Ordinary', pp. 100-119 in Murray and Ouellette.

KRISTEVA, J. (1982) Powers of Horror. New York: Columbia University Press.

LAWTON, J. (1998) 'Contemporary Hospice Care: The Sequestration of the Unbounded Body and Dirty Dying' Sociology of Health \& IIIness 20(2): 121-43. [doi:10.1111/1467-9566.00094]

LUKKEN, G. (2005) Rituals in Abundance. Leuven: Peeters.

MANGAN, L. (2009) 'At Peace - And Finally out of the Limelight', Guardian 23 March.

MCILWAIN, C.D. (2005) When Death Goes Pop: Death, Media and the Remaking of Community. New York: Peter Lang.

MELLOR, P. (1993) 'Death in High Modernity', pp. 11-30 in D. Clark (ed) The Sociology of Death. Oxford: Blackwell.

MELLOR, P. \& Shilling, C. (1993) 'Modernity, Self-Identity and the Sequestration of Death', Sociology 27(3): 411-32. [doi:10.1177/0038038593027003005]

MILLER, W.I. (1997) The Anatomy of Disgust. Cambridge: Harvard University Press.

MITFORD, J. (1963) The American Way of Death. London: Hutchison.

MOIR, J. (2009) 'Personal View', Daily Mail 23 March, pp. 8-9.

MURRAY, S. and Ouellette, L., eds (2009) Reality TV. New York: New York University Press, $2^{\text {nd }}$ edn.

PETERSSON, A. (2010) 'The Production of a Proper Place of Death', in A. Maddrell and J. Sidaway, eds Deathscapes. Aldershot: Ashgate.

PICARDIE, R. (1998) Before I Say Goodbye. London: Penguin.

PROTHERO, S. (2001) Purified by Fire: A History of Cremation in America. Berkeley: University of California Press.

ROJEK, C. (2001) Celebrity. London: Reaktion.

SANTINO, J., ed. (2006) Spontaneous Shrines and the Public Memorialization of Death. Basingstoke: Palgrave Macmillan.

SEALE C. (2002a). Cancer Heroics: A Study of News Reports with Particular Reference to Gender. Sociology 36 (1) 107-126. [doi:10.1177/0038038502036001006]

SEALE C. (2002b) Media and Health. London: Sage.

SIMONDS, W. \& Rothman, B.K. (1992) Centuries of Solace: Expressions of maternal grief in popular literature. Philadelphia: Temple University Press.

SPARKS, C. (2007) 'Reality TV: the Big Brother phenomenon', International Socialism 114.

http://www.isj. org.uk/index. php4?id=314\&issue $=114$

TOMLINSON, J. and M. (2005) The Luxury of Time. London: Pocket Books.

WALTER, T., Pickering, M., Littlewood, J. (1995) 'Death in the News: The Public Invigilation of Private Emotion', Sociology 29: 579-96. [doi:10.1177/0038038595029004002]

WALTER, T. (2008) The New Public Mourning', in M. Stroebe et al, eds Handbook of Bereavement Research and Practice. Washington, DC: American Psychological Association.

WILLMOTT, H. (2000) 'Death. So What? Sociology, Sequestration and Emancipation', Sociological Review 
48(4): 649-65. [doi:10.1111/1467-954X.00237]

YOUNG, T. (2009) 'Status Anxiety', Spectator 25 March. 